\title{
KUALITAS HIDUP PENDERITA PENYAKIT HIPERTENSI PESERTA PROLANIS DI PUSKESMAS KECAMATAN PADANG UTARA KOTA PADANG TAHUN 2017
}

\author{
Abdiana \\ (Fakultas Kedokteran Universitas Andalas)
}

\begin{abstract}
Hypertension is the highest prevalence of visits every year. Data from the Health Office in Padang in 2013 showed that the visit of hypertension sufferers in 2013 was the highest visit with 6,714 new hypertension case visits and 35,054 old case visits. For this reason, it is necessary to conduct research in the context of maintaining health for BPJS Health participants who suffer from chronic diseases to achieve optimal quality of life, especially hypertension. The purpose of this study was to determine the quality of life of hypertension sufferers of Prolanis participants in Padang Utara District, Padang City. The study was conducted with a cross sectional design of hypertension disease prolanis participants in the district of Padang Utara, Padang City in 2017 as many as 126 people. The sampling technique is simple random sampling. Data were analyzed univariately and bivariately with Chi-square test. The results showed that most hypertension sufferers aged $\geq 60$ years old, low educated, female sex, low education, married status and long suffered from hypertension $<10$ years. The conclusion of this study is that there is a significant relationship between marital status and the quality of life of hypertensive illnesses of prolanis participants in Padang Utara Subdistrict, Padang City. It is suggested that the Puskesmas formulate efforts to prevent hypertension and be a source of data for research organizations and other parties involved in preventing hypertension.
\end{abstract}

Keywords : quality of life; hypertension; prolanis

\section{PENDAHULUAN}

Program Pengelolaan Penyakit Kronis (Prolanis) adalah suatu sistem pelayanan kesehatan dan pendekatan proaktif yang dilaksanakan secara terintegrasi yang melibatkan peserta, fasilitas kesehatan dan BPJS Kesehatan dalam rangka pemeliharaan kesehatan bagi peserta BPJS Kesehatan yang menderita penyakit kronis untuk mencapai kualitas hidup yang optimal dengan biaya pelayanan kesehatan yang efektif dan efisien. Tujuan yang ingin dicapai dari kegiatan Prolanis ini adalah mendorong peserta penyandang penyakit kronis mencapai kualitas hidup optimal dengan indikator $75 \%$ peserta terdaftar yang berkunjung ke FKTP memiliki hasil "baik" pada pemeriksaan spesifik terhadap hipertensi sesuai panduan klinis terkait sehingga dapat mencegah timbulnya komplikasi penyakit. ${ }^{1}$

Kegiatan Prolanis salah satunya berupa penyakit hipertensi dikarenakan penyakit tersebut dapat ditangani ditingkat primer dan dilakukan untuk mencegah terjadinya komplikasi. Hipertensi masih merupakan tantangan besar di Indonesia. Betapa tidak, hipertensi merupakan kondisi yang sering ditemukan pada pelayanan kesehatan primer kesehatan. Hal itu merupakan masalah kesehatan dengan prevalensi yang tinggi, yaitu 
sebesar 25,8\%, sesuai dengan data Riskesdas 2013. Di samping itu, pengontrolan hipertensi belum adekuat meskipun obat-obatan yang efektif banyak tersedia. ${ }^{2}$ Dengan mengetahui gejala dan faktor risiko terjadinya hipertensi diharapkan penderita dapat melakukan pencegahan dan penatalaksanaan dengan modifikasi gaya hidup sehingga komplikasi yang terjadi dapat dihindarkan dan dapat meningkatkan kualitas hidup.

Berdasarkan data Dinas Kesehatan kota Padang tahun 2013, Kunjungan penderita hipertensi Tahun 2013 merupakan kunjungan tertinggi yaitu sebanyak 6.714 kunjungan kasus baru hipertensi dan 35.054 kunjungan kasus lama. Kemudian diikuti oleh diabetes mellitus (11.769 total kunjungan). Berdasarkan data tersebut diketahui bahwa penyakit hipertensi menduduki prevalensi kunjungan tinggi setiap tahunnya. ${ }^{3}$

Kecamatan Padang Utara merupakan salah satu Kecamatan yang memiliki prevalensi tinggi kejadian hipertensi. Kecamatan Padang Utara memiliki tiga Puskesmas yaitu Puskesmas Ulak karang, air tawar dan alai. Berdasarkan survey awal, didapatkan informasi bahwa penderita penyakit hipertensi banyak yang datang berobat ke Puskesmas, namun diantara penderita tersebut tidak semua yang mengikuti program prolanis. Prolanis bertujuan untuk menurunkan risiko komplikasi dan mencapai kualitas hidup yang baik dengan pemanfaatan biaya yang efektif dan rasional. Namun program ini tidak berjalan optimal. Jumlah peserta terdaftar prolanis mengalami peningkatan setiap tahun, namun persentase peserta yang melakukan kunjungan rutin justru mengalami tren penurunan.

Menurut Yudianto (2008), kualitas hidup penting untuk diteliti guna membantu petugas kesehatan untuk mengetahui keadaan kesehatan seseorang, sehingga dapat menjadi arahan atau patokan dalam menentukan intervensi yang sesuai dengan keadaan pasien, serta sebagai upaya tindakan pencegahan komplikasi pada penderita penyakit (Yudianto, 2008).

Berdasarkan uraian tersebut, perlu diadakan penelitian yang bertujuan untuk mengetahui kualitas hidup penderita penyakit hipertensi peserta Prolanis di Puskesmas Kecamatan Padang Utara Kota Padang.

\section{METODE PENELITIAN}

Penelitian ini merupakan penelitian observasional dengan rancangan cross sectional. pendekatan Cross sectional yaitu suatu penelitian untuk mempelajari dinamika korelasi antara variabel bebas dan terikat yaitu untuk mengetahui kualitas hidup penyakit hipertensi peserta prolanis di Puskesmas Kecamatan Padang Utara Kota Padang. Pada penelitian ini sampel berjumlah 126 orang penyakit hipertensi. Teknik sampling yang digunakan pada penelitian adalah dengan teknik simple random sampling. ${ }^{4}$ Data dianalisis secara bivariat dengan mengunakan uji chi-square. ${ }^{5}$ 


\section{HASIL PENELITIAN}

Pada penelitian ini karakteristik responden dapat dilihat pada tabel 1 sebagai berikut:

Tabel 1 Distribusi frekuensi Responden Berdasarkan Variabel Dependen dan Independen Penyakit Hipertensi di Puskesmas Kecamatan Padang Utara Kota Padang

\begin{tabular}{|c|c|c|}
\hline Variabel Dependen & Frekuensi (f) & Persentase (\%) \\
\hline \multicolumn{3}{|l|}{ Kualitas Hidup } \\
\hline Buruk & 31 & 24,6 \\
\hline Baik & 95 & 75,4 \\
\hline Jumlah & 126 & 100 \\
\hline \multicolumn{3}{|l|}{ Variabel Independen } \\
\hline \multicolumn{3}{|l|}{ Umur } \\
\hline$\geq 60$ tahun & 82 & 65,1 \\
\hline 45-59 tahun & 37 & 29,4 \\
\hline$<45$ tahun & 7 & 5,6 \\
\hline Jumlah & 126 & 100,0 \\
\hline \multicolumn{3}{|l|}{ Jenis Kelamin } \\
\hline Perempuan & 103 & 81,7 \\
\hline Laki-laki & 23 & 18,3 \\
\hline Jumlah & 126 & 100,0 \\
\hline \multicolumn{3}{|l|}{ Pendidikan } \\
\hline Rendah & 109 & 86,5 \\
\hline Tingqi & 17 & 13,5 \\
\hline Jumlah & 126 & 100,0 \\
\hline \multicolumn{3}{|l|}{ Pekerjaan } \\
\hline Tidak bekerja & 102 & 81,0 \\
\hline Bekerja & 24 & 19,0 \\
\hline Jumlah & 126 & 100,0 \\
\hline \multicolumn{3}{|l|}{ Status Menikah } \\
\hline Janda/Duda & 46 & 36,5 \\
\hline Menikah & 80 & 63,5 \\
\hline Jumlah & 126 & 100,0 \\
\hline \multicolumn{3}{|l|}{ Lama menderita Penyakit } \\
\hline$\geq 10$ tahun & 21 & 16,7 \\
\hline$<10$ tahun & 105 & 83,3 \\
\hline Jumlah & 126 & 100,0 \\
\hline
\end{tabular}

Berdasarkan tabel 1. dapat diketahui bahwa sebagian besar responden memiliki kualitas hidup baik sebesar $75,4 \%$, di ikuti dengan $65,1 \%$ responden berusia $\geq 60$ tahun, $81,7 \%$ responden berjenis kelamin perempuan, $86,5 \%$ responden memiliki tingkat pendidikan rendah, $81 \%$ responden tidak bekerja, $63,5 \%$ responden menikah dan $83,3 \%$ responden menderita penyakit hipertensi $<10$ tahun.

Untuk melihat hubungan umur, jenis kelamin, pendidikan, pekerjaan, status menikah dan lama menderita penyakit dengan kualitas hidup penderita penyakit hipertensi dapat dilihat pada tabel 2 sebagai berikut: 
Tabel 2. Hubungan Variabel Independen dengan Variabel Dependen Pada Penderita Hipertensi di Puskesmas Kecamatan Padang Utara Kota Padang

\begin{tabular}{|c|c|c|c|c|c|c|c|c|}
\hline \multirow{3}{*}{ Variabel } & \multicolumn{4}{|c|}{$\begin{array}{l}\text { Kualitas Hidup Penderita } \\
\text { Hipertensi }\end{array}$} & \multirow{2}{*}{\multicolumn{2}{|c|}{ Total }} & \multirow{3}{*}{$\begin{array}{l}\text { POR } \\
(95 \% \mathrm{Cl})\end{array}$} & \multirow[t]{3}{*}{$\begin{array}{l}\mathrm{p}- \\
\text { value }\end{array}$} \\
\hline & \multicolumn{2}{|c|}{ Buruk } & \multicolumn{2}{|c|}{ Baik } & & & & \\
\hline & f & $\%$ & $f$ & $\%$ & f & $\%$ & & \\
\hline \multicolumn{9}{|l|}{ Umur } \\
\hline$\geq 60$ tahun & 16 & 37,2 & 27 & 62,8 & 43 & 100 & & \multirow[t]{4}{*}{0,05} \\
\hline 45-59 tahun & 14 & 18,4 & 62 & 81,6 & 76 & 100 & & \\
\hline$<45$ tahun & 1 & 14,3 & 6 & 85,7 & 7 & 100 & & \\
\hline Total & 31 & 24,6 & 95 & 75,4 & 126 & 100 & & \\
\hline \multicolumn{9}{|c|}{ Jenis Kelamin } \\
\hline Perempuan & 23 & 22,3 & 80 & 77,7 & 103 & 100 & \multirow{3}{*}{$\begin{array}{l}0,539 \\
(0,203-1,430)\end{array}$} & \multirow[t]{3}{*}{0,32} \\
\hline Laki-laki & 8 & 34,8 & 15 & 65,2 & 23 & 100 & & \\
\hline Total & 31 & 24,6 & 95 & 75,4 & 126 & 100 & & \\
\hline \multicolumn{9}{|l|}{ Pendidikan } \\
\hline Rendah & 26 & 23,9 & 83 & 76,1 & 109 & 100 & \multirow{3}{*}{$\begin{array}{l}0,752 \\
(0,242-2,333)\end{array}$} & \multirow[t]{3}{*}{0,76} \\
\hline Tinggi & 5 & 29,4 & 12 & 70,6 & 17 & 100 & & \\
\hline Total & 31 & 24,6 & 95 & 75,4 & 126 & 100 & & \\
\hline \multicolumn{9}{|l|}{ Pekerjaan } \\
\hline Tidak bekerja & 26 & 25,5 & 76 & 74,5 & 102 & 100 & \multirow{3}{*}{$\begin{array}{l}1,300 \\
(0,441-3,832)\end{array}$} & \multirow[t]{3}{*}{0,83} \\
\hline Bekerja & 5 & 20,8 & 19 & 79,2 & 24 & 100 & & \\
\hline Total & 31 & 24,6 & 95 & 75,4 & 126 & 100 & & \\
\hline \multicolumn{9}{|c|}{ Status Menikah } \\
\hline Janda/Duda & 18 & 39,1 & 28 & 60,9 & 46 & 100 & \multirow{3}{*}{$\begin{array}{l}3,313 \\
(1,432-7,655)\end{array}$} & \multirow[t]{3}{*}{0,00} \\
\hline Menikah & 13 & 16,3 & 67 & 83,8 & 80 & 100 & & \\
\hline Total & 31 & 24,6 & 95 & 75,4 & 126 & 100 & & \\
\hline \multicolumn{9}{|c|}{$\begin{array}{ll}\text { Lama } & \text { menderita } \\
\text { Penyakit } & \end{array}$} \\
\hline$\geq 10$ tahun & 8 & 38,1 & 13 & 61,9 & 21 & 100 & \multirow{3}{*}{$\begin{array}{l}2,194 \\
(0,811-5,933)\end{array}$} & \multirow[t]{3}{*}{0,19} \\
\hline$<10$ tahun & 23 & 21,9 & 82 & 78,1 & 105 & 100 & & \\
\hline Total & 31 & 24,6 & 95 & 75,4 & 126 & 100 & & \\
\hline
\end{tabular}

Pada tabel 2 menunjukkan bahwa persentase kualitas hidup penderita penyakit hipertensi yang buruk lebih tinggi pada kelompok umur $\geq 60$ tahun $(37,2 \%)$ dan umur 45-59 tahun $(18,4 \%)$ dibanding yang berusia $<60$ tahun $(14,3 \%)$. Berdasarkan uji statistik didapatkan nilai $p=0,05(p \leq 0,05)$ yang artinya terdapat hubungan umur dengan kualitas hidup penderita penyakit hipertensi peserta prolanis di Kecamatan Padang Utara Kota Padang.

Persentase kualitas hidup penderita penyakit hipertensi yang buruk lebih tinggi pada jenis kelamin laki-laki $(34,6 \%)$ dibanding jenis kelamin perempuan $(22,3 \%)$. Berdasarkan uji statistik didapatkan nilai $p=0,324$ yang artinya tidak terdapat hubungan jenis kelamin dengan kualitas hidup penderita penyakit hipertensi peserta prolanis di Kecamatan Padang Utara Kota Padang. Persentase kualitas hidup penderita penyakit hipertensi yang buruk lebih tinggi pada tingkat pendidikan tinggi $(29,4 \%)$ dibanding yang tingkat pendidikan rendah $(23,9 \%)$. Berdasarkan uji statistik didapatkan nilai $p=0,848$ yang artinya tidak terdapat 
hubungan pendidikan dengan kualitas hidup penderita penyakit hipertensi peserta prolanis di Kecamatan Padang Utara Kota Padang.

Persentase kualitas hidup penderita penyakit hipertensi yang buruk lebih tinggi pada responden yang tidak bekerja (25,5\%) dibanding yang bekerja (20,8\%). Berdasarkan uji statistik didapatkan nilai $p=0,831$ yang artinya tidak terdapat hubungan pekerjaan dengan kualitas hidup penderita penyakit hipertensi peserta prolanis di Kecamatan Padang Utara Kota Padang. Persentase kualitas hidup penderita penyakit hipertensi yang buruk lebih tinggi pada status janda/duda $(39,1 \%)$ dibanding yang menikah $(16,3 \%)$. Berdasarkan uji statistik didapatkan nilai $\mathrm{p}=0,008$ yang artinya terdapat hubungan status menikah dengan kualitas hidup penderita penyakit hipertensi peserta prolanis di Kecamatan Padang Utara Kota Padang. Persentase kualitas hidup penderita penyakit hipertensi yang buruk lebih tinggi pada lama menderita penyakit hipertensi $\geq 10$ tahun $(38,1 \%)$ dibanding lama menderita penyakit $<10$ tahun $(21,9 \%)$. Berdasarkan uji statistik didapatkan nilai $p=0,195$ yang artinya tidak terdapat hubungan lama menderita penyakit hipertensi dengan kualitas hidup penderita penyakit hipertensi peserta prolanis di Kecamatan Padang Utara Kota Padang.

\section{PEMBAHASAN}

\section{Kualitas Hidup Penderita Penyakit Hipertensi}

Pada penelitian ini didapatkan sebagian besar responden memiliki kualitas hidup baik. Hasil penelitian ini sama dengan penelitian yang dilakukan Fithria didapatkan sebagian besar penderita hipertensi mempunyai kualitas hidup baik $(56,3 \%) .{ }^{6}$ Kualitas hidup adalah tingkatan yang menggambarkan keunggulan seorang individu yang dapat dinilai dari kehidupan mereka. Kualitas hidup individu tersebut biasanya dapat dinilai dari kondisi fisiknya, psikologis, hubungan sosial dan lingkungannya. ${ }^{7}$ Kualitas hidup dari dimensi fisik dapat dinilai dari indikator ADL (Activities of Daily Living), ketergantungan pada bahan obat dan bantuan medis, energi dan kelelahan, mobilitas, nyeri dan ketidaknyamanan, tidur dan istirahat, kemampuan bekerja. Kualitas hidup dari dimensi psikologis dapat dinilai dari indikator gambaran diri dan penampilan, perasaan negatif, perasaan positif, harga diri, spiritualitas/agama/kepercayaan, berpikir, belajar, ingatan (memori) dan konsentrasi. Kualitas hidup dari dimensi hubungan sosial dapat dinilai dari indikator hubungan personal, dukungan sosial, aktivitas seksual.

Kualitas hidup dari dimensi lingkungan dapat dinilai dari indicator sumber pendapatan, kebebasan, keamanan secara fisik, kesehatan dan perawatan sosial: aksesibilitas dan kualitas, lingkungan rumah, peluang untuk mendapatkan informasi baru dan keterampilan, partisipasi dan peluang untuk rekreasi, lingkungan fisik (polusi/bising/lalu lintas/ iklim dan transportasi. ${ }^{8}$ Pada penelitian ini kualitas hidup penderita hipertensi dari dimensi fisik 
didapatkan sebesar $75,17 \%$, dimensi psikologi sebesar $74,12 \%$, dimensi hubungan sosial sebesar $77,18 \%$ dan dimensi lingkungan sebesar $78,75 \%$. Hal ini menunjukan bahwa kualitas hidup penderita hipertensi di Puskesmas Kecamatan Padang Utara kota Padang tergolong baik.

\section{Hubungan Umur dengan Kualitas Hidup Penderita Penyakit Hipertensi}

Hasil analisa deskriptif menunjukkan sebagian besar responden berumur $\geq 60$ tahun $(65,1 \%)$. Hasil penelitian ini sama dengan penelitian yang dilakukan Fithria didapatkan sebagian besar penderita hipertensi berumur $(46,87 \%) .{ }^{6}$ Penelitian ini sama juga dengan penelitian yang dilakukan oleh Dewi PR yang menunjukkan mayoritas responden berada dalam kelompok umur 60 - 74 tahun yaitu masuk dalam katagori lanjut usia, sebesar $62.1 \%$ dari total responden. Usia rata-rata dari responden adalah 71.78. Usia atau harapan hidup dari seseorang individu memiliki hubungan dengan angka kesakitan dan kematian. Prevalensi penyakit hipertensi lebih banyak ditemukan pada orang dewasa yaitu 6-15\% sebagai suatu proses degeneratif. Ditemukan adanya kecendrungan peningkatan prevalensi menurut peningkatan usia. ${ }^{9}$

Hasil analisis hubungan umur dengan kualitas hidup penderita penyakit hipertensi peserta prolanis didapatkan persentase kualitas hidup penderita penyakit hipertensi yang buruk lebih tinggi pada kelompok umur $\geq 60$ tahun $(37,2 \%)$ dan umur $45-59$ tahun $(18,4 \%)$ dibanding yang berusia $<60$ tahun $(14,3 \%)$. Berdasarkan uji statistik didapatkan nilai $p=0,05$ yang artinya terdapat hubungan umur dengan kualitas hidup penderita penyakit hipertensi peserta prolanis di Kecamatan Padang Utara Kota Padang. Usia yang berisiko menderita penyakit hipertensi adalah usia diatas 40 tahun. Pada usia tersebut sudah mulai menderita penyakit degenerative sehingga kualitas hidup mulai menurun. Penelitian Kumar menjelaskan bahwa umur sangat mempengaruhi tingkat kualitas hidup seseorang. Kelompok usia yang lebih tua memiliki kualitas hidup yang lebih rendah. ${ }^{10}$

\section{Hubungan Jenis Kelamin dengan Kualitas Hidup Penderita Penyakit Hipertensi}

Hasil analisa deskriptif menunjukkan sebagian besar responden berjenis kelamin perempuan $(81,7 \%)$. Hasil penelitian ini sama dengan penelitian yang dilakukan Fithria didapatkan sebagian besar penderita hipertensi berjenis kelamin perempuan $(81,2 \%){ }^{6}$ Penelitian ini juga sama dengan penelitian Dewi PR yang menyatakan bahwa sebagian besar responden berjenis kelamin perempuan (65.5\%). ${ }^{9}$ Jenis kelamin merupakan salah satu karakteristik orang yang dapat mempengaruhi terjadinya penyakit. Menurut teori segita epidemiologi yang salah satu yang mempengaruhi derajat kesehatan adalah host. Host adalah segala sesuatu yang melekat pada diri seseorang yang mempengaruhi timbulnya penyakit, salah satunya adalah jenis kelamin. Jenis kelamin sangat berkaitan dengan sifat keterpaparan dan tingkat kerentanan suatu penyakit. Berdasarkan teori, jenis kelamin laki- 
laki dan perempuan mempunyai beberapa perbedaan dalam hal menghadapi faktor fisik dan kejiwaan (Kusuma H, 2011).

Hasil analisis hubungan jenis kelamin responden dengan kualitas hidup penderita penyakit hipertensi peserta prolanis didapatkan Persentase kualitas hidup penderita penyakit hipertensi yang buruk lebih tinggi pada jenis kelamin laki-laki (34,6\%) dibanding jenis kelamin perempuan (22,3\%). Berdasarkan uji statistik didapatkan nilai $p=0,324$ yang artinya tidak terdapat hubungan jenis kelamin dengan kualitas hidup penderita penyakit hipertensi peserta prolanis di Kecamatan Padang Utara Kota Padang. Fadda dan Jiron mengatakan bahwa laki-laki dan perempuan memiliki perbedaan dalam peran serta akses dan kendali terhadap berbagai sumber sehingga kebutuhan atau hal-hal yang penting bagi laki-laki dan perempuan juga akan berbeda. Hal ini mengindikasikan adanya perbedaan aspek-aspek kehidupan dalam hubungannya dengan kualitas hidup pada laki-laki dan perempuan. ${ }^{11}$

\section{Hubungan Pendidikan dengan Kualitas Hidup Penderita Penyakit Hipertensi}

Hasil penelitian ini menunjukan $86,5 \%$ responden memiliki tingkat pendidikan rendah. Pendidikan rendah dalam penelitian ini adalah tingkat pendidikan dari SMA ke bawah. Tingkat pendidikan bukan merupakan faktor risiko penyakit hipertensi, namun tingkat pendidikan mempengaruhi perilaku terhadap kesehatan. Hasil analisis hubungan pendidikan responden dengan kualitas hidup penderita penyakit hipertensi peserta prolanis didapatkan Persentase kualitas hidup penderita penyakit hipertensi yang buruk lebih tinggi pada tingkat pendidikan tinggi $(29,4 \%)$ dibanding yang tingkat pendidikan rendah $(23,9 \%)$. Berdasarkan uji statistik didapatkan nilai $\mathrm{p}=0,848$ yang artinya tidak terdapat hubungan pendidikan dengan kualitas hidup penderita penyakit hipertensi peserta prolanis di Kecamatan Padang Utara Kota Padang. Tingginya tingkat pendidikan seseorang belum tentu berprilaku hidup sehat. karena informasi kesehatan tidak hanya didapatkan di pendidikan formal tapi juga bisa didapat dari pendidikan non formal.

Penelitian yang dilakukan oleh Wahl et.all menemukan bahwa kualitas hidup akan meningkat seiring dengan lebih tingginya tingkat pendidikan yang didapatkan oleh individu. ${ }^{12}$ Tingkat pendidikan adalah salah satu faktor yang dapat mempengaruhi kualitas hidup, hasil penelitian menunjukkan bahwa tingginya signifikansi perbandingan dari pasien yang berpendidikan tinggi meningkat dalam keterbatasan fungsional yang berkaitan dengan masalah emosional dari waktu ke waktu dibandingkan dengan pasien yang berpendidikan rendah serta menemukan kualitas hidup yang lebih baik bagi pasien berpendidikan tinggi dalam domain fisik dan fungsional, khususnya dalam fungsi fisik, energi/kelelahan, social fungsi, dan keterbatasan dalam peran berfungsi terkait dengan masalah emosional. ${ }^{13}$ 


\section{Hubungan Pekerjaan dengan Kualitas Hidup Penderita Penyakit Hipertensi}

Pada penelitian ini lebih banyak ditemukan responden sebagai ibu rumah tangga.. Hasil analisa univariat dari 126 responden menunjukkan sebagian besar responden tidak bekerja (81\%). Hasil penelitian ini sama dengan penelitian yang dilakukan Fithria didapatkan sebagian besar penderita hipertensi tidak bekerja $(81,2 \%) .{ }^{6}$ Hasil analisis hubungan pekerjaan responden dengan kualitas hidup penderita penyakit hipertensi peserta prolanis didapatkan Persentase kualitas hidup penderita penyakit hipertensi yang buruk lebih tinggi pada responden yang tidak bekerja $(25,5 \%)$ dibanding yang bekerja $(20,8 \%)$.

Berdasarkan uji statistik didapatkan nilai $p=0,831$ yang artinya tidak terdapat hubungan pekerjaan dengan kualitas hidup penderita penyakit hipertensi peserta prolanis di Kecamatan Padang Utara Kota Padang. Penelitian yang dilakukan oleh Hultman, Hemlin, dan H"ornquist menunjukkan dalam hal kualitas hidup juga diperoleh hasil penelitian yang tidak jauh berbeda dimana individu yang bekerja memiliki kualitas hidup yang lebih baik dibandingkan individu yang tidak bekerja. ${ }^{14}$

\section{Hubungan Status Menikah dengan Kualitas Hidup Penderita Penyakit Hipertensi}

Hasil penelitian menunjukkan sebagian besar responden menikah (63,5\%). Hasil penelitian ini sama dengan penelitian yang dilakukan Fithria didapatkan sebagian besar penderita hipertensi sudah menikah $(56,3 \%){ }^{6}$ Penelitian yang dilakukan Dewi PR menunjukkan bahwa $74.1 \%$ masih didampingi oleh pasangan hidup masing-masing, dan $24.1 \%$ suami atau istrinya telah meninggal, hanya satu orang $(1.7 \%)$ dari responden yang tidak menikah. ${ }^{9}$ Hasil analisis hubungan status menikah responden dengan kualitas hidup penderita penyakit hipertensi peserta prolanis didapatkan Persentase kualitas hidup penderita penyakit hipertensi yang buruk lebih tinggi pada status janda/duda $(39,1 \%)$ dibanding yang menikah (16,3\%). Berdasarkan uji statistik didapatkan nilai $p=0,008$ yang artinya terdapat hubungan status menikah dengan kualitas hidup penderita penyakit hipertensi peserta prolanis di Kecamatan Padang Utara Kota Padang. Hubungan status perkawinan dengan kualitas hidup penderita penyakit hipertensi didapatkan nilai $\mathrm{OR}=3,3$ yang artinya responden dengan status duda/janda berisiko 3,3 kali mengalami kualitas hidup buruk dibanding responden yang status menikah.

Status perkawinan merupakan salah satu risiko terjadinya penyakit hipertensi karena status perkawinan merupakan salah satu dukungan social terhadap pasien sehingga dengan adanya pasangan hidup dapat memberikan dukungan kepada pasangan untuk menjalankan perilaku hidup sehat. Secara umum menunjukkan bahwa individu yang menikah memiliki kualitas hidup yang lebih tinggi dari pada individu yang tidak menikah, bercerai, ataupun janda atau duda akibat pasangan meninggal Responden yang sudah menikah akan mempunyai cara beradaptasi yang baik dan tepat dari pasangannya. Dengan keberadaan pasangan yang selalu mendampingi, memberikan dukungan pada saat 
responden mengalami masalah kesehatan sehingga pasangan lebih optimis dalam menjalani perawatan kesehatan yang akan berdampak baik untuk kehidupannya. Oleh karena itu responden dengan status menikah mempunyai kualitas hidup lebih baik (Kusuma $H, 2011)$.

\section{Hubungan Lama Menderita Penyakit Hipertensi dengan Kualitas Hidup Penderita Penyakit Hipertensi}

Hasil penelitian menunjukkan sebagian besar responden menderita penyakit hipertensi $<10$ tahun (83,3\%). Hasil penelitian ini sama dengan penelitian yang dilakukan Fithria didapatkan sebagian besar responden menderita penyakit hipertensi $<10$ tahun $(81,2 \%){ }^{6}$ Hasil analisis hubungan lama menderita hipertensi dengan kualitas hidup penderita penyakit hipertensi peserta prolanis didapatkan. Persentase kualitas hidup penderita penyakit hipertensi yang buruk lebih tinggi pada lama menderita penyakit hipertensi $\geq 10$ tahun $(38,1 \%)$ dibanding lama menderita penyakit $<10$ tahun $(21,9 \%)$.

Berdasarkan uji statistik didapatkan nilai $p=0,195$ yang artinya tidak terdapat hubungan lama menderita penyakit hipertensi dengan kualitas hidup penderita penyakit hipertensi peserta prolanis di Kecamatan Padang Utara Kota Padang. Responden yang lama menderita penyakit memiliki pengalaman yang baik dalam mengelola penyakitnya. Hasil penelitian ini sama dengan penelitian yang dilakukan oleh Damayanti bahwa responden lebih banyak ditemukan dengan satus menikah (76,7\%) dan kualitas hidup yang kurang lebih banyak pada responden yang lama mengalami hipertensi $\geq 5$ tahun dibanding lama mengalami hipertensi $<5$ tahun. Semakin lama seseorang menderita penyakit hipertensi, maka semakin rendah kualitas hidupnya. ${ }^{15}$

\section{SIMPULAN DAN SARAN}

Pada penelitian ini dapat disimpulkan bahwa sebagian besar penderita penyakit hipertensi berumur $\geq 60$ tahun, berjenis kelamin perempuan, tingkat pendidikan rendah, tidak bekerja, status menikah dan lama menderita penyakit hipertensi $<10$ tahun. dan terdapat hubungan sataus menikah dengan kualitas hidup penderita penyakit hipertensi di Kecamatan Padang Utara Kota Padang. Penelitian ini dapat menjadi masukan bagi pihak puskesmas khususnya program Prolanis untuk merumuskan upaya pencegahan penyakit hipertensi dan menjadi sumber data bagi organisasi riset yang terkait dalam pencegahan penyakit hipertensi sehingga kualitas hidup penderita penyakit hipertensi meningkat.

\section{DAFTAR PUSTAKA}

1. BPJS Kesehatan. Panduan Layanan Bagi Peserta BPJS Kesehatan.; 2014.

2. Balitbang Kemenkes RI. Riset Kesehatan Dasar (RISKESDAS).; 2013.

3. Dinas Kesehatan Kota Padang. Laporan Tahunan tahun 2013 Edisi 2014. 
4. Lemeshow. Besar Sampel Dalam Penelitian Kesehatan. Yogyakarta: UGM; 2007.

5. Notoatmodjo, Soekidjo. Metodologi Penelitian Kesehatan. Jakarta: Rineka Cipta; 2012.

6. Fithria. Kualitas Hidup Penderita Hipertensi di Desa Lamceu Kecamatan Kuta Baro Aceh Besar. Idea Nurs J. 2011;II(1).

7. WHO. The World Health Organization Quality of Life (WHOQOL)-BREF. 2004.

8. Center For Disease Control and Prevention CDC. Health-Related Quality of Life (HRQOL).

9. Rossyana Dewi P, Wayan Sudhana I, Kunci K, Hidup K. Gambaran Kualitas Hidup Pada Lansia Dengan Normotensi Dan Hipertensi Di Wilayah Kerja Puskesmas Gianyar I Periode Bulan November Tahun 2013 Quality of Life in Elderly With Normotension or Hypertension in Puskesmas Gianyar 1 Area of Work During November 20. 2013:1-14.

10. Ganesh Kumar S, Majumdar A, Pavithra G. Quality of life and its associated factors using WHOQOL- BREF among elderly in Urban Puducherry, India. J Clin Diagnostic Res. 2014;8(1):54-57. doi:10.7860/JCDR/2014/6996.3917

11. Fadda G, Jirón P. Quality of life and gender: A methodology for urban research. Environ Urban. 1999;11(2):261-270. doi:10.1630/095624799101285011

12. Wahl AK, Rustøen T, Hanestad BR, Lerdal A, Moum T. Quality of life in the general Norwegian population, measured by the Quality of Life Scale (QOLS-N). Qual Life Res. 2014;13(5):1001-1009. doi:10.1023/B:QURE.0000025583.28948.5b

13. Barbareschi G, Sanderman R, Leegte IL, Van Veldhuisen DJ, Jaarsma T. Educational level and the quality of life of heart failure patients: A longitudinal study. J Card Fail. 2011;17(1):47-53. doi:10.1016/j.cardfail.2010.08.005

14. Hultman, B., Hemlin, S., \& Olof Hörnquist J. Quality of life among unemployed and employed people in northern Sweden. Are there any differences? Work. 2016;26(1):47-56.

15. Damayanti S. Hubungan dukungan keluarga dengan kualitas hidup lansia penderita hipertensi di dusun grujugan bantul yogyakarta. 2018 . 